\title{
Long-term impact of exotic ants on the native ants of Madeira
}

\author{
JAMES K. WETTERER ${ }^{1}$, XAVIER ESPADALER 2 , \\ ANDREA L. WETTERER ${ }^{3}$, DORA AGUIN-POMBO ${ }^{4}$ and \\ A N T Ó N I O M. F R A N Q U I N H O - A G U I A R ${ }^{5}{ }^{1}$ Wilkes Honors College, Florida Atlantic University, \\ U.S.A., ${ }^{2}$ Ecology Unit, Universidad Autónoma de Barcelona, Spain, ${ }^{3}$ Department of Ecology, Evolutionary, \& Environmental \\ Biology, Columbia University, U.S.A., ${ }^{4}$ Centre for Macaronesian Studies, University of Madeira, Portugal, \\ and ${ }^{5}$ Laboratório Agr' cola da Madeira, Portugal
}

\begin{abstract}
The earliest exotic records for two notorious invasive ants, the big-headed ant (Pheidole megacephala) and the Argentine ant (Linepithema humile), both come from the Atlantic islands of Madeira, where the two species underwent population explosions in the 1850s and 1890s respectively. Researchers have long assumed that these invaders spread across all of Madeira and exterminated most or all native ants, despite no research actually documenting such impact.

2. Re-examination of first-hand nineteenth century accounts suggest that $P$. megacephala and L. humile may never have spread beyond coastal lowland areas, representing $<10 \%$ of Madeira's land area. In 2002, native ants dominated most of Madeira; P. megacephala and L. humile were restricted to $\approx 0.3 \%$ and $\approx 6 \%$ of Madeira's land area respectively.

3. Of the 10 native ant species known from Madeira, only one (Temnothorax wollastoni) was not present in 1999-2002 surveys. Although exotic ants may have exterminated $T$. wollastoni, it seems likely that this species still survives.

4. Thus, even after 150 or more years of residence, P. megacephala and L. humile have come to occupy only a small part of Madeira, and appear to have had little impact.

5. Most of Madeira may be too cool for P. megacephala and perhaps too moist for L. humile to dominate. Also, Madeira's vast natural areas may generally lack weedy vegetation that can support high densities of plant-feeding Hemiptera critical for the ecological dominance of invasive ants. Finally, a dominant native ant, Lasius grandis, inhabiting $\approx 84 \%$ of Madeira, may actively exclude $P$. megacephala and L. humile.
\end{abstract}

Key words. Argentine ant, big-headed ant, biodiversity, biological invasions, exotic species, Formicidae, Lasius grandis, Linepithema humile, Madeira, Pheidole megacephala.

\section{Introduction}

Exotic species, spread through human commerce, are threatening native species worldwide. The impact of exotics is considered one of the two major ongoing causes (along with destruction of native habitat) leading to the decline and extinction of species

Correspondence: James K. Wetterer, Wilkes Honors College, Florida Atlantic University, 5353 Parkside Drive, Jupiter, FL 33458, U.S.A. E-mail: wetterer@fau.edu
(Wilson, 1992). Several ant species are known to have major ecological impacts in exotic locales (Hölldobler \& Wilson, 1990; Williams, 1994). When these species invade, they commonly experience enormous population explosions and come to dominate widespread areas. Where these species occur at high densities, they negatively impact native species and act as important agricultural pests by enhancing populations of phloem-feeding Hemiptera (Hölldobler \& Wilson, 1990).

Two of the most widespread and destructive invasive ants are the big-headed ant (Pheidole megacephala (Fabricius)), originally from tropical Africa, and the Argentine ant (Linepithema 
humile (Mayr), formerly Iridomyrmex humilis), originally from subtropical South America. Where P. megacephala occurs in high densities, this species can be remarkably thorough in exterminating native ant species (Wetterer, 2002). For example, Wheeler (1908) surveyed ants on the tiny Caribbean island of Culebrita, and reported that $P$. megacephala 'was nesting under every stone and log, from the shifting sand of the sea-beach to the walls of the light-house on the highest point of the island. The most careful search failed to reveal the presence of any other species ... It is highly probable that $P h$. megacephala ... had exterminated all the other ants which must have previously inhabited Culebrita.' In areas where it dominates, L. humile is also highly destructive to native species. The spread and impact of $L$. humile has received much attention, no doubt because it is a major pest in the USA and Europe (e.g. see Human \& Gordon, 1997; Suarez et al., 1998; Holway, 1999; Wetterer et al., 2001).

Early invasions by P. megacephala and L. humile: Hawaii, Bermuda, and Madeira

Although $P$. megacephala is primarily tropical and L. humile is primarily subtropical, some areas have been invaded by both species, notably the tropical Pacific islands of Hawaii and the subtropical Atlantic islands of Bermuda. In both locales, $P$. megacephala and L. humile appear to have had great longterm impacts on the local biota over extensive areas. Pheidole megacephala invaded Hawaii in the nineteenth century, and by 1880 it was dominant through much of the lowlands (Blackburn \& Kirby, 1880). Linepithema humile was a later arrival, first collected in Hawaii in 1940 (Zimmerman, 1941). Currently, P. megacephala is the dominant ant below $1000 \mathrm{~m}$ elevation in Hawaii, whereas L. humile is largely absent from the Hawaiian lowlands, and instead dominates areas above 1000 m elevation (Skaife, 1955; Cole et al., 1992; Reimer, 1994; Wetterer, 1997, 1998; Wetterer et al., 1998). Numerous authors have documented how P. megacephala and L. humile have caused drastic reductions in the populations of native invertebrate species in Hawaii (e.g. Zimmerman, 1948; Cole et al., 1992; Reimer, 1994). Pheidole megacephala was first recorded in Bermuda in 1889 (Dahl, 1892), and was by far the most dominant ant species there in the early twentieth century (Haskins, 1939). When L. humile arrived in Bermuda in the 1940s, this new invader quickly overran much territory, driving back $P$. megacephala. Pheidole megacephala, however, persisted, and ever since, these two species have been contesting ever-shifting battlefronts between mutually exclusive territories that together occupy most of the land area of Bermuda (Haskins, 1939; Haskins \& Haskins, 1965, 1988; Crowell, 1968; Lieberburg et al., 1975; Wetterer \& Wetterer, 2004). In addition to the two dominant ant species, 18 other ant species are known from Bermuda, though currently all are inconspicuous and/or very rare (Wetterer \& Wetterer, 2004).

Remarkably, the earliest known exotic records for both $P$. megacephala and L. humile come from the subtropical Atlantic islands of Madeira, where these two species underwent population explosions in the 1850 s and 1890 s respectively (Heer, 1852; Schmitz, 1896). Numerous researchers have drawn parallels between the successive invasions of $P$. megacephala and L. humile in Hawaii and Bermuda and events that took place earlier in Madeira. Many of these retellings report how $P$. megacephala and/or L. humile impacted the native ants of Madeira. Some even reported that these exotic ants had completely exterminated most or all the native ants of Madeira (e.g. Newell \& Barber, 1913; Wheeler, 1922, 1934; Donisthorpe, 1927; Haskins, 1939; Brian, 1956; Skaife, 1961; Larson \& Larson, 1965; Haskins \& Haskins, 1965, 1988; Simberloff, 1978). For example, Haskins and Haskins (1965) wrote: 'Heer's careful studies $(1852,1856)$ leave no doubt that by the middle of the nineteenth century Pheidole megacephala had supplanted the entire native ant fauna of Madeira. By 1898 it had itself been as completely supplanted by $I$. humilis.' This account, if true, would be remarkable. Published reports concerning the impacts of exotic ants in Madeira, however, misrepresent actual firsthand observations (see Wetterer, 2006a); no previous study has examined the impact of $P$. megacephala and L. humile on any native species in Madeira. The present paper evaluates the possible long-term impacts of $P$. megacephala and L. humile on the native ants of Madeira.

\section{Nineteenth century records of ants in Madeira}

Oswald Heer, a Swiss botanist and paleontologist, visited Madeira from winter 1850 to spring 1851. Heer's (1852) article 'On the house ant of Madeira' (in German, translated into English in 1856) described how P. megacephala was 'found on the whole south side of the island of Madeira, up to a height of about 1000 feet above the sea, in incalculable numbers, especially in hot sunny places. In turning over 10 stones in such places, these ants are pretty sure to be living under eight. In the city of Funchal there can scarcely be a house which does not harbour millions of these creatures.' Heer (1852) did not mention any impact of $P$. megacephala on other ants, and mentioned only one other ant species in Madeira, Formica fusca L.

In 1894, Ernst Schmitz, a German priest and ornithologist who moved to Madeira in 1878 (da Silva \& de Menezes, 1940), sent ant specimens to Auguste Forel, a Swiss psychiatrist and myrmecologist, for identification. Forel (1895) wrote (translated here from German): 'to my surprise Mr Schmitz twice sent me from Madeira the typical Iridomyrmex humilis Mayr from the Neotropical fauna, which is already a house and land pest in Madeira.' Schmitz (1896); translated here from Portuguese) published a detailed account of the $L$. humile outbreak in Madeira, writing: 'in Funchal and its outskirts, ants have become, in the past few years, a true plague and public calamity. By the millions they invade everything, fields, gardens, parks, and particularly houses... Outside the city of Funchal and its outskirts, [L. humile] already often dominates on the southern coast of Madeira. On the east and north coast of the island it is still uncommon.' Schmitz (1896) wrote that P. megacephala had 'fled entirely from Funchal and its suburbs ahead of the South American invader. Only at a distance of one league from Funchal, near the S. Gonçalo crossroad, in sandy and rocky land, can it be encountered.' Although Schmitz (1896) did not evaluate the impact of $L$. humile on native ants, he cautioned 
that 'It must be feared, as Dr Forel says, that Iridomyrmex will destroy little by little all the other local species and it will not delay also to invade the south of Europe.

Although nineteenth century reports did not examine the impact of exotic ants on native ants in Madeira, nineteenth century ant collections allow us to examine long-term changes in the ant fauna of Madeira. The earliest ant collection on Madeira was made by Thomas V. Wollaston, an English coleopterist who visited Madeira numerous times beginning in 1847 . Wollaston's only published reference to Madeiran ants concerned a beetle inhabiting $P$. megacephala nests (Wollaston, 1854). Other authors, however, published records of 12 ant species from Madeira based on specimens that Wollaston collected (Smith, 1858; Saunders, 1903; Donisthorpe, 1940; Bolton, 1977, 1980, 1987; Tables 1 and 2). Smith (1858) also listed unattributed records for two ant species from Madeira (F. fusca and Paratrechina longicornis). A second major ant collection in nineteenth century Madeira was made by Schmitz (1896), who wrote: 'I endeavored to document the principal ant species currently existing in the Madeira archipelago and the Selvagens, encouraged by Dr Forel, who in good will offered to classify and describe all the material sent to him.' In total, Forel (1895, 1904) identified 14 ant species among the specimens sent by Schmitz (Tables 1 and 2). The ant collections in Madeira by Wollaston and Schmitz coincided with the outbreaks of $P$. megacephala and L. humile respectively. Between these periods, Mayr $(1865,1876)$ and Emery $(1882,1893)$ published records of minor ant collections from Madeira, totalling six species (Tables 1 and 2).

The present study attempted to document all ant species ever collected in Madeira, based on published accounts and examination of ant specimens collected by Wollaston and Schmitz. Then, in 2002, ants were collected in Madeira to determine which species are still present and thus evaluate whether Forel's

Table 1. Madeira ant records during the outbreaks of Pheidole megacephala (a) and Linepithema humile (c), between the outbreaks (b), and after the outbreaks (d-e), and the documented range on Atlantic islands and inferred origin and status of each species.

\begin{tabular}{|c|c|c|c|}
\hline & Madeira records & Atlantic range & Origin/status \\
\hline \multicolumn{4}{|l|}{ Native ants } \\
\hline Lasius grandis Forel & abcde & _zmc___ & M \\
\hline Plagiolepis schmitzii Forel & a_cde & zmc___ & M \\
\hline Monomorium carbonarium (Smith) & abcde & zm_ & $\mathrm{E}$ \\
\hline Tapinoma madeirense Forel & a_cde & $-\mathrm{m}$ & M \\
\hline Monomorium subopacum (Smith) & abcde & _-meva_ & M \\
\hline Hypoponera eduardi (Forel) & a_c_e & _zmcv__ & M \\
\hline Myrmecina graminicola (Latreille) & e & $-\mathrm{m}$ & $\mathrm{P}$ \\
\hline Temnothorax unifasciatus (Latreille) & $\overline{\mathrm{a} \_} \mathrm{e}$ & $\bar{z} \mathrm{zm}$ & M \\
\hline Pheidole pallidula (Nylander) & $\ldots$ & _mc & M \\
\hline Temnothorax wollastoni (Donisthorpe) & $\bar{a}$ & $-\mathrm{m}$ & $\mathrm{E}$ \\
\hline \multicolumn{4}{|l|}{ Exotic ants } \\
\hline Linepithema humile (Mayr) & a_cde & bzmc_h h & NT \\
\hline Tetramorium caldarium Roger & a_c_e & bzmcv_h & PT \\
\hline Paratrechina longicornis (Latreille) & $\mathrm{ab} \_\mathrm{e}$ & bzmcvah & OT \\
\hline Cardiocondyla emeryi Forel & $\overline{c d e}$ & b_mcvah & AT \\
\hline Pheidole megacephala (Fabricius) & a_c_e & bzmcvah & $\mathrm{AT}$ \\
\hline Hyроропеra sp. & e & $\ldots$ & $?$ \\
\hline Solenopsis sp. 1 & e & $? \mathrm{zm} \_?$ & $? \mathrm{~T}$ \\
\hline Hypoponera punctatissima (Roger) & $\overline{a b \_} e$ & bzmcv_h & MT \\
\hline Paratrechina jaegerskioeldi (Mayr) & - & $-\mathrm{mc}_{-}^{-}$ & MT \\
\hline Cardiocondyla mauritanica Forel & {$[\mathrm{e}$} & - mc_a_ & MT \\
\hline Pyramica membranifera (Emery) & e & _m_v_ & AT \\
\hline Strumigenys silvestrii Emery & {$[\mathrm{e}$} & $-\mathrm{m}$ & $\mathrm{N}$ \\
\hline Technomyrmex albipes (Smith) & 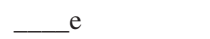 & _-m_v__ & OT \\
\hline Solenopsis sp. 2 & e & $-\mathrm{m}$ & $? \mathrm{~T}$ \\
\hline Monomorium pharaonis (L) & {$[\mathrm{e}$} & _- me__ & OT \\
\hline Tetramorium bicarinatum (Nyl.) & $\overline{a \_c}$ & _zmcv__ & AT \\
\hline Messor structor (Latreille) & $-c_{-}$ & $-\mathrm{m}$ & M \\
\hline Camponotus sp. & $\bar{b}$ & ${ }_{-} \mathrm{m}$ & $?$ \\
\hline
\end{tabular}

Species ordered by number of 1989-2002 records (see Table 3) or date last recorded. Madeira records: a = 1847-58 (Wollaston in numerous sources; Heer, 1852; Smith, 1858), b = 1957-1893 (Mayr, 1865, 1876; Emery, 1882, 1893), c = 1894-1904 (Forel, 1895, 1904; Schmitz, 1896, 1897), d = 1935-67 (Stitz, 1940; Wellenius, 1949; Krauss, unpublished), e = 1989-2002 (Espadaler \& Báez, 1993; present study). Atlantic range: b = Bermuda, $\mathrm{z}=$ Azores, $\mathrm{m}=$ Madeira, $\mathrm{c}=$ Canary Islands, $\mathrm{v}=$ Cape Verde, $\mathrm{a}=$ Ascension, $\mathrm{h}=$ St Helena. Origin $/$ Status: $\mathrm{E}=\mathrm{Macaronesian}, \mathrm{M}=$ Mediterranean, $\mathrm{New}=$ New World, $\mathrm{P}=$ Palearctic, $\mathrm{A}=$ African, $\mathrm{O}=$ Asian, $\mathrm{T}=$ tramp species. 
Table 2. Erroneous Madeiran ant records from the nineteenth century. Symbols as in Table 1 .

\begin{tabular}{|c|c|c|}
\hline Formica fusca & $a_{-}$ & $=$litres. grandis \\
\hline Lasius niger & abc & $=$ litres. grandis \\
\hline Monomorium monomorium & $b_{-}$ & $=$M. carbonarium \\
\hline Monomorium salomonis & $\ldots$ & $=$ M. subopacum \\
\hline Plagiolepis pygmaea & a_c & $=P$. schmitzii \\
\hline Ponera coarctata & $a_{-}$ & $\begin{aligned}= & H . \text { eduardi } \text { and } \\
& H . \text { punctatissima }\end{aligned}$ \\
\hline Tapinoma erraticum & a_c & $=T$. madeirense \\
\hline Tetramorium guineense & $-\mathrm{c}$ & $=T$. bicarinatum \\
\hline Tetramorium simillimum & a_c & $=T$. caldarium \\
\hline
\end{tabular}

prediction that $L$. humile would gradually kill off the native ants of Madeira has, in fact, come to pass.

\section{Study site}

The subtropical Atlantic archipelago of Madeira, off the coast of North Africa, was originally settled by the Portuguese in the early 1400s, and is now an autonomous region of Portugal. Only the two largest islands, Madeira $\left(737 \mathrm{~km}^{2}\right)$ and Porto Santo $\left(41 \mathrm{~km}^{2}\right)$, are currently inhabited. In addition, there are more than 50 smaller, uninhabited islands $\left(17 \mathrm{~km}^{2}\right.$ total $)$, including two island clusters to the south, the Desertas and Selvagens. At $32.6^{\circ} \mathrm{N}$, Funchal, Madeira is at approximately the same latitude as Hamilton, Bermuda $\left(32.3^{\circ} \mathrm{N}\right)$.

Madeira is part of the Macaronesian biogeographic subregion, which also includes the Azores, Canary Islands, Cape Verde Islands, and part of the north-west African coast. The islands of Macaronesia have acted as a biological conservatory, preserving a large number of species found nowhere else in the world. The absence of many important mainland competitors and predators has allowed the survival of many relicts of the subtropical biota that inhabited the Mediterranean area before the end of the Tertiary Period, two million years ago. Madeira is particularly known for its ancient Laurisilva stands, a broadleaf evergreen forest. In addition, many groups of endemic plants, animals, and fungi have diversified tremendously in Macaronesia (Wollaston, 1854; Enghoff, 1992; Hobohm, 2000). For example, Madeira has 216 species of land snails, twice as many as all of Britain (Cook, 1996).

The island of Madeira is very mountainous, with $90 \%$ of its land area above $500 \mathrm{~m}$ elevation, and $33 \%$ above $1000 \mathrm{~m}$ (Sziemer, 1999). Most of Madeira's population lives along the southern coast, below $500 \mathrm{~m}$ elevation, leaving much of the rest of the island relatively undisturbed. The easternmost tip of the island of Madeira (Ponta de São Lourenço) is much drier than the rest of the island; the smaller islands of Porto Santo, the Desertas, and the Selvagens are also semiarid. Two-thirds of the island of Madeira, many small islands around Porto Santo, and all of the Desertas and Selvagens are protected as nature reserves. Madeira's Laurisilva forest is now protected as a United Nations World Heritage Site.

\section{Methods}

\section{Museum specimens}

In 1861, Wollaston sold a collection of his ant specimens from Madeira to the Oxford University Natural History Museum (ONHM). This entire collection, which had remained intact in its original drawer, was examined by XE. All these specimens, collected sometime between 1847 and 1858, were undated and labelled with taxonomic determinations by Smith and Forel.

Wollaston deposited other ant specimens from Madeira at the British Natural History Museum (BNHM). A Wollaston syntype of Temnothorax wollastoni (Donisthorpe) from the BNHM was examined by XE. Wollaston's other specimens at the BNHM, identified by B. Bolton, were examined by JKW. Wollaston's ant specimens from Madeira at the BNHM were all labelled '1858.' Although Wollaston made his fifth visit to Madeira in 1858, this label may instead indicate that Smith (1858) catalogued Wollaston's specimens in that year.

Schmitz (1896) deposited a set of ant specimens in the Seminary Museum in Funchal, but curators at the Natural History Museum in Bom Sucesso, Madeira, where the Seminary collection now resides, reported that most of the collection, including all ant specimens, had been destroyed in a fire.

Forel deposited ant specimens he received from Schmitz at the Musée d'Histoire Naturelle in Geneva (MHNG). Schmitz's Madeira specimens, representing all species listed by Schmitz $(1896,1897)$ and Forel $(1895,1904)$ that were not found occurring in Madeira in 2002, were examined by XE to evaluate possible misidentifications. All these specimens, collected between 1894 and 1904, were undated and labelled with Forel's taxonomic determinations.

The ant collections at the Smithsonian Institute's National Museum of Natural History (SI) in Washington DC, and the Museum of Comparative Zoology (MCZ) at Harvard University were searched for additional ant specimens from Madeira. Ants collected by Arechavaleta et al. (2000) were also examined by XE. Specimens from Madeira reported by Mayr $(1865,1876)$ and Emery $(1882,1893)$ could not be obtained.

\section{New collections}

Between 1989 and 2002, ants were sampled opportunistically by AMFA and several other researchers at the Laboratorio Agricola da Madeira (J. Jesus, J. Andrade, V. Pereira, A. Fernandes, and J.P. de Carvalho), primarily at urban and agricultural sites.

All other new collections were made in 2002. JKW and ALW collected ants through visual search and sifting soil and litter samples in a wide variety of habitats, particularly concentrating on garden, urban, and semiarid areas, where exotic ants could be found. The primary goal was to collect the maximum number of different ant species in the time allotted. Using such direct sampling methods proves much more efficient than site-standardised techniques designed for evaluating relative abundances of species and making detailed comparisons among a limited number of sites (such as the ALL protocol, which requires a minimum of 3 days sampling per site; Agosti \& Alonso, 2000; Fisher et al., 
2000). Ants were collected by XE and DAP through visual search and vegetation beating, primarily in less disturbed areas and in gardens. Several undergraduates at the University of Madeira in Funchal collected ants from inside their homes.

\section{Classification of sites and species}

In the distribution analyses of ants collected by JKW and ALW, all sites that were not currently heavily disturbed by human activity were classified as less disturbed. These sites included not only relatively pristine forest and heath, but also secondary forest, planted pine forest, and grazed seminatural meadow. Under this broad definition, less-disturbed areas of Madeira included almost $90 \%$ of Madeira's land area. Sites heavily disturbed by human activity were divided into three categories: urban (built up areas without flower gardens), garden (tended flower gardens), and agriculture (tended crops). Lessdisturbed sites, garden sites, and urban sites were subdivided by aridity (semiarid $=$ sites on Madeira's Ponta de São Lourenço, plus Porto Santo, the Desertas, and the Selvagens; non-arid = all others). Non-arid, less-disturbed sites were subdivided by elevation (low: < $500 \mathrm{~m}$; medium: 500-1000 m; high: > $1000 \mathrm{~m}$ ); all semiarid sites were $<500 \mathrm{~m}$ elevation and all disturbed sites were $<700 \mathrm{~m}$ elevation. All agricultural sites except one were non-arid. Mixed-use sites were categorised according to the predominant habitat. The amount of Madeira's land area currently fitting each of these categories was estimated using a variety of sources (e.g. Sziemer, 1999; INE, 2001), then the overall occurrence of ants in Madeira was estimated by multiplying the proportion of sites where each species was found in a particular habitat type by the estimated proportion of Madeira's land area matching that habitat type and summing across all habitat types.

The native vs. exotic status of each ant species was evaluated based primarily on its known worldwide distribution. All New World species and all tramp species distributed around the world through human commerce were considered exotic to Madeira. Ant species not widely distributed beyond Macaronesia (the Azores, Madeira, the Canary Islands, and Cape Verde) and the Mediterranean, were classified as native to Madeira (i.e. predating human arrival), with two exceptions described below.

\section{Statistics}

To evaluate possible impact of $P$. megacephala and L. humile on native and exotic ants in Madeira, mean species counts at collection sites with and without these two exotic species present were compared using two-tailed $t$-tests without assuming equal variance between samples.

\section{Results}

\section{Species counts}

Combining past and present collections, 28 ant species (10 native; 18 exotic) were recorded from Madeira (Table 1), 27 based on examination of specimens, including 10 new records (one native; nine exotic). One of these species, Camponotus sylvaticus (Olivier) (reported by Mayr, 1865), could not be verified with specimens from Madeira, and therefore is listed as Camponotus sp. Two species of thief ants, Solenopsis spp., were not classified to species because the taxonomy of this group is in disarray. One taxon reported from Madeira, Plagiolepis schmitzii madeirensis Emery, was determined by XE to be a junior synonym of another taxon present, Plagiolepis schmitzii Forel. Tapinoma erraticum var. madeirense Forel was raised by $\mathrm{XE}$ to a full species, and the European Tapinoma ambiguum Emery was determined to be a junior synonym of Tapinoma madeirense. A detailed taxonomic analysis of the ants of Madeira will be published elsewhere (Wetterer et al. unpub. ms.).

Based on examinations of museum specimens by XE, published records of seven ant species from nineteenth century Madeira were determined to be misidentifications (Table 2). Two additional species records, Formica fusca and Monomorium monomorium Bolton, were probably also misidentifications. Heer's (1852) and Smith's (1858) Madeiran records of F. fusca were almost certainly Lasius grandis Forel, by far the most common ant now on Madeira. Wheeler (1927) noted that an early record of $F$. fusca from the Canary Islands was probably Lasius niger (L), and he omitted $F$. fusca from his list of known Madeiran ants. Mayr (1865) reported Monomorium minutum Mayr (now Monomorium monomorium) from Madeira, but this was probably a misidentification of the very common Monomorium carbonarium (F. Smith), which at the time was considered a subspecies of M. minutum.

In total, 17 ant species (eight native; nine exotic) were collected in Madeira before 1904, and 24 ant species (nine native; 15 exotic) were collected between 1995 and 2002. These included a previously unreported $L$. humile specimen in the BNHM collected by Wollaston in Madeira between 1847 and 1858. In 2002, 22 ant species were collected in Madeira and specimens for two other species collected in 1995 (by AMFA) and 1999 (by M. Arechavaleta) were examined. Four ant species (one native; three exotic) collected before 1904 were not collected in 2002; 11 species (two native; nine exotic) collected between 1995 and 2002 were not collected before 1904 .

Although there is necessarily some uncertainty in evaluating native vs. exotic status, the classifications of most ant species in Madeira, including all common species, appear to be robust. Tentative natives include only Myrmecina graminicola and Pheidole pallidula, the former known from Europe, the latter from the Mediterranean. Doubts arise primarily because these species were first found in Madeira only recently (1989 and 1999 respectively). Tentative exotics include three species not known to be tramp species: Camponotus sp., Hypoponera sp., and Messor structor (Latreille). Mayr (1865) reported Camponotus sylvaticus collected in Madeira by the Novara Expedition, which spent 9 days in Funchal in November 1857 (Mayr, 1865). Camponotus sylvaticus is a soil-nesting European species that seems unlikely to occur in Madeira. This record was probably a different species of exotic Camponotus that temporarily infested an imported wood product (see Wetterer \& Wetterer, 2004). Hypoponera sp. was classified as exotic because it is also known from St Helena in the South Atlantic and 
it may be synonymous with a Hypoponera known from Japan (XE unpublished data). Schmitz (1896) found Messor structor only in an urban flower garden in Funchal and considered this conspicuous Mediterranean species to be an exotic in Madeira.

\section{Ant records in 1989-2002 collections}

Because different collectors made new ant collections using different methods, in different habitats, and for different purposes, data from each collector were analysed separately.

Between 1989 and 2002, 12 ant species (four native; eight exotic) were recorded by AMFA and researchers from the Laboratorio Agricola da Madeira, primarily from urban and agricultural sites (Table 3). Despite this collection coming almost exclusively from highly disturbed environments, with a probable bias toward conspicuous and pest species, the three most commonly recorded species were all native. The most common exotic ant collected, L. humile, was a distant fourth. It was the subjective impression of AMFA that L. humile was less common in 2002 than it was 10 years earlier.

Arechavaleta et al. (2000) listed Monomorium salomonis (L) (identified by XE) collected in 1999 on two arid islands in the far south of Madeira, Selvagem Pequena and Selvagem Grande. A re-examination of these specimens by XE indicated that these specimens actually were M. subopacum. Arechavaleta et al. (2000) accidentally omitted a record of Pheidole pallidula (Nylander) from Selvagem Grande in 1999.

Twenty ant species (seven native; 13 exotic) were collected by JKW and ALW at 94 sites on Madeira and 19 sites on Porto Santo (Tables 3 and 4). Lasius grandis was the most common species collected; Tetramorium caldarium Roger was the most common exotic ant collected. These records are analysed more thoroughly below.

Five ant species (all native) were collected by DAP and two undergraduates at the University of Madeira (Élvio Nunes and Iola Martins) in 196 standardised vegetation-beating samples from relatively natural habitat. Every sample had only one ant species present. Lasius grandis was by far the most common ant collected, making up over $90 \%$ of the samples (Table 3).

Seventeen ant species (eight native; nine exotic) were collected by XE at 23 sites on Madeira, primarily in relatively natural areas, but also in a few urban gardens. The four most commonly recorded species were all native; Tetramorium caldarium and Paratrechina longicornis (Latreille) were the most common exotics.

Table 3. Ant species collected Madeira in 1989-2002.

\begin{tabular}{|c|c|c|c|c|c|c|c|}
\hline & D1 & D2 & D3 & D4 & D5 & D6 & D7 \\
\hline Samples & 195 & 2 & 113 & 196 & 24 & 4 & 10 \\
\hline$\%$ native species & 77 & 100 & 60 & 100 & 75 & 46 & 85 \\
\hline \multicolumn{8}{|l|}{ Native ants (no. of records) } \\
\hline Lasius grandis & 78 & - & 61 & 177 & 14 & - & 4 \\
\hline Plagiolepis schmitzii & 32 & - & 46 & 3 & 12 & 2 & 3 \\
\hline Monomorium carbonarium & 32 & - & 35 & - & 9 & 2 & 3 \\
\hline Tapinoma madeirense & 6 & - & 13 & 12 & 10 & - & - \\
\hline Monomorium subopacum & - & 2 & 20 & - & 2 & 2 & 1 \\
\hline Hypoponera eduardi & - & - & 16 & - & 4 & - & - \\
\hline Myrmecina graminicola & - & - & 9 & 2 & 4 & - & - \\
\hline Temnothorax unifasciatus & - & - & - & 2 & 1 & - & - \\
\hline +Pheidole pallidula & - & 1 & - & - & - & - & - \\
\hline \multicolumn{8}{|l|}{ Exotic ants (no. of records) } \\
\hline Linepithema humile & 18 & - & 28 & - & 3 & 3 & 1 \\
\hline Tetramorium caldarium & 4 & - & 40 & - & 6 & 2 & - \\
\hline Paratrechina longicornis & 9 & - & 21 & - & 5 & 1 & - \\
\hline Cardiocondyla emeryi & 1 & - & 20 & - & 1 & 1 & - \\
\hline Pheidole megacephala & 8 & - & 7 & - & 1 & - & - \\
\hline Hypoponera sp. & - & - & 14 & - & 1 & - & - \\
\hline +Solenopsis sp. 1 & - & - & 9 & - & - & - & - \\
\hline Hypoponera punctatissima & - & - & 6 & - & - & - & - \\
\hline +Paratrechina jaegerskioeldi & 1 & - & 3 & - & 1 & - & - \\
\hline + Cardiocondyla mauritanica & - & - & 3 & - & 1 & - & - \\
\hline +Pyramica membranifera & - & - & 2 & - & - & - & - \\
\hline +Strumigenys silvestrii & 1 & - & 1 & - & - & - & - \\
\hline +Technomyrmex albipes & - & - & 1 & - & - & - & 1 \\
\hline +Solenopsis sp. 2 & - & - & - & - & 1 & - & - \\
\hline + Monomorium pharaonis & 1 & - & - & - & - & - & - \\
\hline
\end{tabular}

$+=$ species not previously reported from Madeira. D1 = 1989-2002; AMFA et al.; disturbed sites, D2 = 1999; Arechavaleta; natural sites, D3 = 2002; JKW and ALW; primarily disturbed sites, D4 = 2002; DAP; natural sites, D5 = 2002; XE; mostly natural sites, D6 = 2002; XE and DAP; arid sites, D7 = 2002; University of Madeira students; inside houses. 
Seven ant species (three native; four exotic) were collected by XE and DAP at four arid sites on Porto Santo. Linepithema humile was the most commonly collected species.

Undergraduates at the University of Madeira collected six ant species (four native, two exotic) from their homes in and around Funchal. The three most commonly collected species were natives. Two exotics, L. humile and Technomyrmex albipes (F. Smith), were collected only once each. Because T. albipes had no previous records from Madeira, the student's apartment was visited by JKW and ALW where T. albipes was also collected outdoors in nearby flower gardens.

\section{Ant species distributions in 2002}

Subdividing samples collected by JKW and ALW, average total species count was fairly consistent across all habitat types except gardens, averaging 2.1-2.8 species per site. Species composition, however, showed striking differences among the different habitat types (Table 4). Non-arid less-disturbed site samples (LN, MN, HN in Table 4) had virtually only native ant species (92-100\% of species records), semiarid less-disturbed sites (DN) had $64 \%$ native species records, and urban and agri- cultural sites (U, DU, A) had about half native species records (40-54\%). Flower garden sites (G, DG) had higher total species counts (4.4-4.7 species per site), about twice that of other sites; fewer than half the site records (43-45\%) were for native species. Pheidole megacephala was found in a very limited area: 15 records in Funchal and one record $5 \mathrm{~km}$ west of Funchal. Linepithema humile was widespread in highly disturbed lowland habitats, but essentially absent from less-disturbed habitats, except in semiarid areas.

Comparing species counts at the 85 sites without $L$. humile and the 28 sites with $L$. humile, mean number of native species was significantly higher at the former $(2.0 \pm 1.1$ vs. $1.2 \pm 1.3$; $t_{2}=3.09$, d.f. $\left.=40.9, P=0.004\right)$, mean number of other exotic species was not significantly different $(1.0 \pm 1.5$ vs. $1.4 \pm 1.7$; $t_{2}=-1.04$, d.f. $\left.=41.2, P=0.30\right)$, mean number of all other species was not significantly different $(3.0 \pm 1.9$ vs. $2.6 \pm 2.7$; $t_{2}=0.84$, d.f. $=36.0, P=0.40$ ).

Comparing species counts at the 106 sites without $P$. megacephala and the seven sites with $P$. megacephala, mean number of native species was significantly higher at the former $(1.9 \pm$ 1.2 vs. $0.6 \pm 1.1 ; t_{2}=3.02$, d.f. $\left.=6.9, P=0.02\right)$, mean number of other exotic species was not significantly different $(1.3 \pm 1.6$ vs. $1.9 \pm 1.6 ; t_{2}=-0.98$, d.f. $\left.=6.9, P=0.36\right)$, mean number of

Table 4. Ants in different habitats (survey by JKW \& ALW in 2002; D3 in Table 3).

\begin{tabular}{|c|c|c|c|c|c|c|c|c|c|c|}
\hline & \multicolumn{5}{|c|}{ Less-disturbed sites } & \multicolumn{5}{|c|}{ Heavily disturbed sites } \\
\hline & $\mathrm{LN}$ & $\mathrm{MN}$ & $\mathrm{HN}$ & $\mathrm{DN}$ & $\mathrm{G}$ & $\mathrm{U}$ & DG & DU & $\mathrm{A}$ & Overall \\
\hline$\%$ land area (est.) & 3 & 47 & 33 & 7 & 0.1 & 2 & 0.1 & 0.3 & 8 & 100 \\
\hline No. of sites surveyed & 5 & 8 & 17 & 16 & 27 & 20 & 5 & 10 & 5 & 113 \\
\hline Mean no. of species per site & 2.4 & 2.5 & 2.2 & 2.3 & 5.0 & 2.8 & 4.4 & 2.5 & 2.6 & 2.4 \\
\hline$\%$ native species & 92 & 100 & 97 & 64 & 43 & 46 & 45 & 40 & 54 & 91 \\
\hline \multicolumn{11}{|l|}{ Native ants ( $\%$ of sites) } \\
\hline Lasius grandis & 100 & 100 & 88 & 6 & 59 & 50 & - & 30 & 40 & 84 \\
\hline Plagiolepis schmitzii & 40 & 50 & 29 & 38 & 55 & 35 & 80 & 10 & 20 & 39 \\
\hline Monomorium carbonarium & 40 & 38 & 12 & 19 & 34 & 40 & 60 & 30 & 20 & 27 \\
\hline Tapinoma madeirense & - & 13 & 65 & - & 3 & - & - & - & - & 27 \\
\hline Monomorium subopacum & - & - & - & 69 & 3 & - & 60 & 30 & 40 & 8.2 \\
\hline Hypoponera eduardi & 40 & 25 & 12 & 6 & 24 & 5 & - & - & 20 & 19 \\
\hline Myrmecina graminicola & - & 25 & - & 6 & 21 & - & - & - & - & 12 \\
\hline \multicolumn{11}{|l|}{ Exotic ants (\% of sites) } \\
\hline Linepithema humile & 20 & - & - & 25 & 31 & 35 & 20 & 40 & 40 & 6.4 \\
\hline Tetramorium caldarium & - & - & - & 38 & 55 & 50 & 60 & 40 & 20 & 5.5 \\
\hline Paratrechina longicornis & - & - & - & - & 24 & 40 & 40 & 30 & 20 & 2.6 \\
\hline Cardiocondyla emeryi & - & - & 6 & - & 34 & 10 & 60 & 20 & 40 & 5.5 \\
\hline Pheidole megacephala & - & - & - & - & 14 & 15 & - & - & - & 0.3 \\
\hline Hypoponera sp. & - & - & - & 19 & 28 & - & 40 & 10 & - & 1.4 \\
\hline Solenopsis sp. 1 & - & - & - & - & 28 & - & 20 & - & - & 0.0 \\
\hline Hypoponera punctatissima & - & - & - & - & 21 & - & - & - & - & 0.0 \\
\hline Paratrechina jaegerskioeldi & - & - & - & - & 10 & - & - & - & - & 0.0 \\
\hline Cardiocondyla mauritanica & - & - & - & - & 7 & - & - & 10 & - & 0.0 \\
\hline Pyramica membranifera & - & - & - & - & 7 & - & - & - & - & 0.0 \\
\hline Strumigenys silvestrii & - & - & - & - & 3 & - & - & - & - & 0.0 \\
\hline Technomyrmex albipes & - & - & - & - & 3 & - & - & - & - & 0.0 \\
\hline
\end{tabular}

Sites were classified as less disturbed $(\mathrm{N})$ or heavily disturbed $(\mathrm{G}=$ garden, $\mathrm{U}=$ urban, $\mathrm{A}=$ agriculture). Sites were subdivided by aridity (D = semiarid; all others = non-arid). Non-arid natural sites were subdivided by elevation (L: < $500 \mathrm{~m}, \mathrm{M}: 500-1000 \mathrm{~m}, \mathrm{H}:>1000 \mathrm{~m})$. See text for more details. 
all other species was not significantly different ( $3.2 \pm 2.1$ vs. $2.4 \pm 2.5 ; t_{2}=0.75$, d.f. $=6.6, P=0.48$ ).

A detailed analysis of each ant species in Madeira, including its ecology and distribution with respect to elevation, precipitation, and disturbance will be published elsewhere (Wetterer et al. unpublished data).

\section{Discussion}

\section{The native and exotic ant fauna}

Combining past and present collections, a total of 28 ant species with reliable records were documented from Madeira; 10 species appear to be native to Madeira and 18 exotic. In contrast, the more temperate Macaronesian archipelago of the Azores has only 14 known ant species (Wetterer et al., 2004), 12 of which have also been collected in Madeira (five native and seven exotic; Table 1). Bermuda, in the Western Atlantic at the same latitude as Madeira, and Saint Helena, in the tropical South Atlantic, both share the same six (or possibly seven) ant species with Madeira, all common tramp species (Table 1; Wetterer \& Wetterer, 2004; small thief ants, Solenopsis spp., found in Bermuda and Saint Helena may be the same as Solenopsis sp. 1).

\section{Distribution and long-term impact of $\mathrm{P}$. megacephala and L. humile}

Heer (1852) and Schmitz (1896) described great nineteenth century plagues of $P$. megacephala and L. humile in Funchal and the south coast of Madeira, with $L$. humile also reaching the east and north coasts. Schmitz (1896) believed that L. humile had been introduced to Madeira 'in recent years.' It was therefore surprising to discover a previously unreported $L$. humile specimen collected in Madeira before 1858 that pre-dates all other known specimens of L. humile, including the type specimens from Argentina collected in 1866 (Mayr, 1868). This raises the question as to why $L$. humile apparently remained uncommon in Madeira from 1858 until about 1890, and then underwent a population explosion. Large populations of L. humile invariably depend heavily on honeydew produced by phloem-feeding Hemiptera, such as aphids, mealybugs, and scale insects. The population explosion of L. humile in Madeira therefore may have been triggered by the arrival in Madeira of a new species of mutualist scale insect or a new crop variety that made a better host for a mutualist scale insect already present in Madeira (see Wilson, 2005).

The great outbreaks of P. megacephala and L. humile, however, apparently did not extend beyond the lowlands, which make up just a small fraction of Madeira's land area. Assuming Heer's (1852) account was accurate, and the great plague of $P$. megacephala occupied the entire south side of Madeira below 1000 feet $(308 \mathrm{~m})$ elevation, this would represent less than $5 \%$ of the island's land area. Schmitz (1896) also mentioned L. humile only in coastal areas of Madeira, suggesting he did not observe them in the interior. Including the east and north coasts of Madeira and much of Porto Santo, L. humile may have spread to as much as $10 \%$ of Madeira. Thus, even at their peak population densities, $P$. megacephala and $L$. humile may have impacted native ant species on only a small portion of Madeira. In addition, the population explosions of $P$. megacephala and L. humile may have been fairly short-lived. For example, the ant specimens reported by Mayr $(1865,1876)$ and Emery $(1882$, 1893 ) included neither $P$. megacephala nor $L$. humile, suggesting that $P$. megacephala populations crashed long before the L. humile outbreak of the 1890s.

In 2002, native ants dominated most of Madeira, despite a higher number of exotic ant species. Exotic ants were completely absent from $\approx 85 \%$ of Madeira. Exotic ants were very rare in less-disturbed non-arid areas (found at 3\% of sites representing $\approx 83 \%$ of Madeira's land area). In contrast, exotic ants were very common in highly disturbed lowland areas (urban, garden, and agricultural sites; found at $87 \%$ of sites representing $\approx 10 \%$ of land area), and fairly common in less-disturbed semiarid areas (found at $56 \%$ of sites representing $\approx 7 \%$ of land area). Surprisingly, in 2002, most house ants collected were Madeira natives. Overall, P. megacephala and L. humile were restricted to about $0.3 \%$ and $6 \%$ of Madeira's land area respectively. Although it is possible that $P$. megacephala, L. humile, and other exotic ants spread to much of Madeira and that the native ant fauna has subsequently rebounded to reclaim most of Madeira, no evidence was found to support this.

At sites with $P$. megacephala or L. humile present, significantly fewer native ant species were present than at sites without these species present. Nonetheless, the long-term impact of $P$. megacephala and L. humile on the native ant fauna of Madeira appears to have been very limited. No evidence was found that $P$. megacephala and L. humile caused any widespread extinction of native ants on Madeira. Of the 10 total native ant species ever recorded in Madeira, the only one not found between 1999 and 2002 was Temnothorax wollastoni, a Madeiran endemic that Donisthorpe (1940) described from specimens collected by Wollaston. It is possible that $T$. wollastoni lived only in parts of Madeira that were overrun by $P$. megacephala and $L$. humile and was driven extinct by these exotics. Further, it is possible that other native ant species were exterminated before they could be collected. Because, however, it appears that exotic ants never invaded most of Madeira, it seems likely that $T$. wollastoni and possibly additional endemic ant species have survived and will be found in the future.

\section{Possible factors limiting the distribution and impact of $\mathrm{P}$. megacephala and $\mathrm{L}$. humile}

Even after about 150 years of residence and population explosions, $P$. megacephala and L. humile have failed to achieve widespread distribution and ecological dominance in Madeira, a result much different than what has been documented in Hawaii and Bermuda (see Introduction). A number of factors may have contributed to this failure, including climate, vegetation, and competitors. The extensive highlands of Madeira may be too cool for the primarily tropical P. megacephala, and most of Madeira may be too moist for L. humile to dominate. In contrast, 
Bermuda, at the same latitude as Madeira, lacks highlands. Interestingly, at high elevations on the Big Island of Hawaii, L. humile dominates on the semiarid western slope of Mauna Kea, but does not penetrate less-disturbed parts of the more humid Kilauea Caldera region (Wetterer, 1998; Wetterer et al., 1998). In addition, most of Madeira's vast protected areas may lack sufficient weedy vegetation to support high densities of plant-feeding Hemiptera critical for the ecological dominance of invasive ants. In fact, the scarcity of appropriate weedy vegetation outside highly disturbed areas may be an important factor limiting the spread of invasive ants in areas with relatively undisturbed native vegetation worldwide.

The presence of dominant native ants, notably Lasius grandis, which occupies an estimated $84 \%$ of Madeira's area, may also play a role in limiting the spread of $P$. megacephala and L. humile. In natural areas of Madeira, L. grandis was by far the most common ant beaten from vegetation, where they were probably tending Hemiptera; presumably L. grandis excludes other ant species from exploiting this resource. Both P. megacephala and L. humile have also invaded the Azores, where they are currently uncommon and restricted only to highly disturbed areas (Wetterer et al., 2004). As in Madeira, the most commonly collected ant in the Azores also is L. grandis (Wetterer et al., 2004). In contrast, Hawaii apparently never had any native ants and Bermuda currently has no dominant native ant species (Wetterer \& Wetterer, 2004). In Bermuda, it is possible that a previously dominant Lasius species was driven extinct by P. megacephala; the first ant identified to species from Bermuda, collected in 1873, was classified as Formica nigra ( $=$ Lasius niger) by Kirby (1884). Unfortunately, Wetterer (2006b) was unable to find any ant specimens from nineteenth century Bermuda, nor any Lasius specimens from Bermuda to confirm this record.

\section{Catastrophic vs. minimal impact of exotic ants}

Observations of great ecological impacts of $P$. megacephala and/or L. humile, particularly in Hawaii and Bermuda, combined with misreading and misrepresentation of first-hand accounts from Madeira, led many researchers to the pessimistic belief that $P$. megacephala and L. humile had similar great impacts in Madeira (see Wetterer, 2006a). The present study, however, indicates that invasions and population explosions of two of the world's most destructive invasive ants do not inevitably lead to long-term ecological dominance and widespread negative impacts on other species. Some other recent studies also offer similar cause for optimism concerning the long-term impacts of destructive exotic ants. After initial population explosions, exotic ants commonly show significant declines in population density (e.g. see Deyrup et al., 2000; Wilson, 2005). As a result, the long-term ecological impact of exotic ant species may not always be as severe as anticipated based on short-term studies conducted at times of peak population densities (Morrison, 2002; Morrison \& Porter, 2003). As long as vulnerable species have invader-free refuges during the peak population densities of invasive ants, recovery is possible after the invaders' populations decline. For example, Torres and Snelling (1997) resurveyed ants on Culebrita, where
P. megacephala had previously exterminated all other ant species (Wheeler, 1908). They found 16 ant species present in 1982, probably colonising Culebrita from nearby islands after $P$. megacephala populations receded.

Still, in the absence of invader-free refuges, invasive ants certainly may drive many native species to extinction. For example, in 2003, JKW (unpublished data) surveyed ants on Monte Gordo, the highest mountain of the Atlantic island of São Nicolau, Cape Verde, and found only P. megacephala at all sites sampled except for sites within $100 \mathrm{~m}$ of the mountain's peak. Here, where $P$. megacephala had not yet spread, a small pocket of other ant species survived, including an endemic species known only from this mountain, Monomorium boltoni Espadaler \& Agosti. If $P$. megacephala continues its spread up the mountain, it seems unlikely that $M$. boltoni will survive once $P$. megacephala overruns what may be its last refuge.

Although Forel's dire prediction that $L$. humile would kill off the native ants of Madeira has not come to pass, another of his predictions was quickly realised. Concerning L. humile, Schmitz (1897) reported 'I had occasion to establish its presence in Lisbon in September 1896. This fulfilled the prediction of Dr. Forel in 1895; that this South American ant, after having invaded Madeira, would quickly make its appearance on the European continent.' In fact, after the records of $L$. humile in Madeira starting before 1858, the next earliest exotic records all come from mainland Portugal (1890-96: Schmitz, 1897; Martins, 1907; Coutinho, 1929) suggesting that L. humile may have spread from South America to southern Europe (and perhaps to other parts of the world) via Madeira and then Portugal (see Wetterer \& Wetterer, 2006).

Pheidole megacephala and L. humile began their worldwide spread in the nineteenth century and have already spread through much of their potential range (JKW, unpublished analysis). Several other highly destructive ants, however, have thus far come to occupy only a small portion of their potential ranges, most notably the little fire ant (Wasmannia auropunctata (Roger)) and the red imported fire ant (Solenopsis invicta (Buren)) (Wetterer \& Porter, 2003; Morrison et al., 2004). More research is needed to analyse not only where various invasive species may be able to become establish based on climatic requirements, but also their potential long-term impact, which may be catastrophic (e.g. in Hawaii and Bermuda) or may be minimal (e.g. in the Azores and Madeira).

\section{Acknowledgements}

We thank M. Wetterer and M. Tunick for comments on this manuscript; T. Hoim for statistical advice; J. Jesus, J. Andrade, V. Pereira, A. Fernandes, and J.P. de Carvalho at the Laboratorio Agricola da Madeira for use of their specimen records; S. Wetterer, É. Nunes, I. Martins, and students of the University of Madeira for collecting ant specimens; the staff of the Natural Park of Madeira for field assistance; B. Bolton of the BNHM for loan of $T$. wollastoni type and permission to work in the BNHM collection; J. Hogan of the ONHM for loan of Wollaston's specimens; B. Merz of the MHNG for loan of Schmitz' specimens; the National Geographic Society, Florida 
Atlantic University, and Centro de Ciência e Tecnologia da Madeira (CITMA) for financial support.

\section{References}

Agosti, D. \& Alonso (2000) The ALL protocol: a standard protocol for the collection of ground-dwelling ants. Ant: Standard Methods for Measuring and Monitoring Biodiversity (ed. by D. Agosti, J.D. Majer, L.E. Alonso \& T.R. Schultz), pp. 204-206. Smithsonian Institution Press, Washington, DC

Arechavaleta, M., Zurita, N. \& Oromí, P. (2000) Nuevos datos sobre la fauna de artrópodos de las Islas Salvajes. Revista de la Academia Canaria de Ciencias, 12, 83-99.

Blackburn, T. \& Kirby, W.F. (1880) Notes on species of aculeate Hymenoptera occurring in the Hawaiian Islands. Entomologists' Monthly Magazine, 17, 85-89.

Bolton, B. (1977) The ant tribe Tetramoriini (Hymenoptera: Formicidae). The genus Tetramorium Mayr in the Oriental and Indo-Australian regions, and in Australia. Bulletin of the British Museum of Natural History (Entomology), 36, 67-151.

Bolton, B. (1980) The ant tribe Tetramoriini (Hymenoptera: Formicidae). The genus Tetramorium Mayr in the Ethiopian zoogeographical region. Bulletin of the British Museum of Natural History (Entomology), 40, 193-384.

Bolton, B. (1987) A review of the Solenopsis genus-group and revision of Afrotropical Monomorium Mayr (Hymenoptera: Formicidae). Bulletin of the British Museum of Natural History (Entomology), 54, 263-452.

Brian, M.V. (1956) Segregation of species of the ant genus Myrmica. Journal of Animal Ecology, 25, 319-337.

Cole, F.R., Medeiros, A.C., Loope, L.L. \& Zuehlke, W.W. (1992) Effects of the Argentine ant on arthropod fauna of Hawaiian highelevation shrubland. Ecology, 73, 1313-1322.

Cook, L.M. (1996) Habitat, isolation and the evolution of Madeiran landsnails. Biological Journal of the Linnaean Society, 59, 457-470.

Coutinho, M.P. (1929) A 'formiga argentina' 'Iridomyrmex humilis' Mayr 'var. arrogans', Santschi. Boletim do Ministério da Agricultura, Ano, XI(13-18), 95-116.

Crowell, K.L. (1968) Rates of competitive exclusion by the Argentine ant in Bermuda. Ecology, 49, 551-555.

Dahl, F. (1892) Die Landfauna von Bermuda. Ergebnisse der PlanktonExpedition 1889 der Humboldt-Stiftung, 1, 105-112.

Deyrup, M., Davis, L. \& Cover, S. (2000) Exotic ants in Florida. Transactions of the American Entomological Society, 126, 293-326.

Donisthorpe, H. (1927) The ants (Formicidae), and some myrmecophiles, of Sicily. Entomological Record and Journal of Variation, 39, 6-9.

Donisthorpe, H. (1940) Descriptions of new species of ants (Hym, Formicidae) from various localities. Annals and Magazine of Natural History, 11(5), 39-48.

Emery, C. (1882) Le crociere dell'yacht 'Corsaro' del capitano armatore Enrico d'Albertis. II. Formiche. Annali del Museo Civico di Storia Naturale, 18, 448-452.

Emery, C. (1893) Voyage de M. Ch. Alluaud aux îles Canaries. Annales de la Société Entomologique de France, 62, 81-88.

Enghoff, H. (1992) Macaronesian millipedes (Diplopoda) with emphasis on endemic species swarms on Madeira and the Canary Islands. Biological Journal of the Linnean Society, 46, 153-161.

Espadaler, X. \& Báez, M. (1993) Myrmecina graminicola (Latr, 1802) (Hymenoptera, Formicidae) in Madeira. Bocagiana, 167, 1-3.
Fisher, B.L.A.K.F., Malsch, R., Gadagkar, J.H.C., Delabie, H.L., Vasconcelos \& Majer (2000) Applying the ALL protocol: selected case studies. Ant: Standard Methods for Measuring and Monitoring Biodiversity (ed. by D. Agosti, J.D. Majer, L.E. Alonso \& T.R. Schultz), pp. 207-214. Smithsonian Institution Press, Washington, DC

Forel, A. (1895) Südpalaearctische Ameisen. Mitteilungen der Schweizerischen Entomologischen Gessellschaft, 9, 227-234.

Forel, A. (1904) Dimorphisme du mâle chez les fourmis et quelques autres notices myrmécologiques. Annales de la Société Entomologique de Belgique, 48, 421-425.

Haskins, C.P. (1939) Of Ants and Men. Prentice Hall, New York.

Haskins, C.P. \& Haskins, E.F. (1965) Pheidole megacephala and Iridomyrmex humilis in Bermuda - equilibrium or slow replacement. Ecology, 46, 736-740.

Haskins, C.P. \& Haskins, E.F. (1988) Final observations on Pheidole megacephala and Iridomyrmex humilis in Bermuda. Psyche, 95, $177-184$.

Heer, O. (1852) Über die Haus-Ameise Madeiras. Jugend Naturforschung Gesellschaft, 54, 1-24.

Heer, O. (1856) On the house ant of Madeira (translated by R.T. Lowe). Annals and Magazine of Natural History, 2(17), 209-224 \& 322333.

Hobohm, C. (2000) Plant species diversity and endemism on islands and archipelagos, with special reference to the Macaronesian Islands. Flora, 195, 9-24.

Hölldobler, B. \& Wilson, E.O. (1990) The Ants. Harvard University Press, Cambridge, Massachusetts.

Holway, D.A. (1999) Competitive mechanisms underlying the displacement of native ants by the invasive Argentine ant. Ecology, 80, 238251.

Human, K.G. \& Gordon, D.M. (1997) Effects of Argentine ants on invertebrate biodiversity in Northern California. Conservation Biology, 11, 1242-1248.

INE (2001) Recenseamento Geral Da Agricultura 1999, Madeira. Instituto Nacional de Estatistica, Portugal, Lisbon.

Kirby, W.F. (1884) On the hymenoptera collected during the recent expedition of H.M.S. 'Challenger'. Annals and Magazine of Natural History, Series 5, XIII, 403-413.

Larson, P.P. \& Larson, M.W. (1965) All About Ants. World Publishing Co., New York.

Lieberburg, I., Kranz, P.M. \& Seip, A. (1975) Bermudian ants revisited: the status and interaction of Pheidole megacephala and Iridomyrmex humilis. Ecology, 56, 473-478.

Martins, M.N. (1907) Une fourmi terrible envahissant l'Europe (Iridomyrmex humilis Mayr). Brotéria, Series Zoología, 6, 101-102.

Mayr, G. (1865) Reise der Österreichischen Fregatte 'Novara' um die Erde in den Jahren 1857, 1858, 1859. Zoologischer Theil Band II Abtheilung 1. K Gerold's Sohn, Wien, Austria.

Mayr, G. (1868) Formicidae novae Americanae collectae a Prof. P. de Strobel. Annuario della Società dei Naturalisti e Matematici. Modena, 3, 161-178.

Mayr, G. (1876) Die australischen Ameisen. Journal des Museums Godeffroy Hamburg, 12, 56-115.

Morrison, L.W. (2002) Long-term impacts of an arthropod-community invasion by the imported fire ant, Solenopsis invicta. Ecology, 83, 2337-2345.

Morrison, L.W. \& Porter, S.D. (2003) Positive association between densities of the red imported fire ant, Solenopsis invicta (Hymenoptera: Formicidae), and generalized ant and arthropod diversity. Environmental Entomology, 32, 548-554.

Morrison, L.W., Porter, S.D., Daniels, E. \& Korzukhin, M.D. (2004) Potential global range expansion of the invasive fire ant, Solenopsis invicta. Biological Invasions, 6, 183-191. 
Newell, W. \& Barber, T.C. (1913) The Argentine ant. United States Department of Agriculture, Bureau of Entomology, Bulletin, 122, $1-98$.

Reimer, N.J. (1994) Distribution and impact of alien ants in vulnerable Hawaiian ecosystems. Exotic Ants: Biology, Impact, and Control of Introduced Species (ed. by D.F. Williams), pp. 11-22. Westview Press, Boulder, Colorado.

Saunders, E. (1903) Hymenoptera aculeate, collected by the Rev. Alfred E Eaton, MA, in the spring of 1902, including notes on species taken by the late T Vernon Wollaston and FA Bellamy. Transactions of the Entomological Society of London, 1903(2), 207-218.

Schmitz, E. (1896) As formigas da Madeira. Annaes de Sciencias Naturaes, 3, 55-58.

Schmitz, E. (1897) As formigas da Madeira. Annaes de Sciencias Naturaes, 4, 77.

da Silva, F.A. \& de Menezes. C.A. (eds) (1940) Elucidário Madeirense, 2nd edn. Centro de Estudios de História do Atlântico, Funchal, Portugal.

Simberloff, D. (1978) Using island biogeographic distributions to determine if colonization is stocastic. American Naturalist, 112, 713-726.

Skaife, S.H. (1955) The Argentine ant Iridomyrmex humilis Mayr. Transactions of the Royal Society of South Africa, 34, 355-377.

Skaife, S.H. (1961) The Study of Ants. Longmans Green, London.

Smith, F. (1858) Catalogue of Hymenopterous Insects in the Collection of the British Museum. Part VI. Formicidae. British Museum, London.

Stitz, H. (1940) Die Arthropodenfauna von Madeira nach den Ergebnissen der Reise von Prof. Dr. O. Lundblad Juli-August 1935. XXIV. Hymenoptera: Formicidae. Arkiv for Zoologi, 32B(5), 1-2.

Suarez, A.V., Bolger, D.T. \& Case, T.J. (1998) Effects of fragmentation and invasion on native ant communities in coastal southern California. Ecology, 79, 2041-56.

Sziemer, P. (1999) Madeira's Natural History in a Nutshell. Francisco Ribeiro \& Filhos, Lda, Funchal, Portugal.

Torres, J.A. \& Snelling, R.R. (1997) Biogeography of Puerto Rican ants: a non-equilibrium case? Biodiversity and Conservation, 6, 1103-1121.

Wellenius, O.H. (1949) Iter entomologicum et botanicum ad insulas Madeiram et Azores anno 1938 a Richard Frey, Ragnar Storå et Carl Cedercreutz factum, 19. Die Formiciden von den Azoren und Madeira. Commentationes Biologicae, 8(19), 1-4.

Wetterer, J.K. (1997) Ants on Cecropia in Hawaii. Biotropica, 29, $128-132$.

Wetterer, J.K. (1998) Non-indigenous ants associated with geothermal and human disturbance in Hawai'i Volcanoes National Park. Pacific Science, 52, 40-50.

Wetterer, J.K. (2002) Ants of Tonga. Pacific Science, 56, 125-135.
Wetterer, J.K. (2006a) Quotation error, citation copying, and ant extinctions in Madeira. Scientometrics, 67, 351-372.

Wetterer, J.K. (2006b) The vanished plague ants (Hymenoptera: Formicidae) of 19th century Bermuda. Myrmecologische Nachrichten, in press.

Wetterer, J.K. \& Porter, S.D. (2003) The little fire ant, Wasmannia auropunctata: distribution, impact, and control. Sociobiology, 42, $1-41$.

Wetterer, J.K. \& Wetterer, A.L. (2004) Ants (Hymenoptera: Formicidae) of Bermuda. Florida Entomologist, 87, 212-221.

Wetterer, J.K. \& Wetterer, A.L. (2006) A disjunct Argentine ant metacolony in Macaronesia and southwestern Europe. Biological Invasions, in press.

Wetterer, J.K., Banko, P.C., Laniawe, L.P., Slotterback, J.W. \& Brenner, G.J. (1998) Non-indigenous ants at high elevations on Mauna Kea, Hawaii. Pacific Science, 52, 228-236.

Wetterer, J.K., Wetterer, A., L. \& Hebard, E. (2001) Impact of the Argentine ant, Linepithema humile, on the native ants of Santa Cruz Island, California. Sociobiology, 38, 709-721.

Wetterer, J.K., Espadaler, X., Wetterer, A.L. \& Cabral, S.G.M. (2004) Native and exotic ants of the Azores (Hymenoptera: Formicidae). Sociobiology, 44, 1-20.

Wheeler, W.M. (1908) The ants of Porto Rico and the Virgin Islands. Bulletin of the American Museum of Natural History, 24, 117-158.

Wheeler, W.M. (1922) Ants of the American Museum Congo expedition. A contribution to the myrmecology of Africa. Bulletin of the American Museum of Natural History, 34, 1-1021.

Wheeler, W.M. (1927) The ants of the Canary Islands. Proceedings of the American Academy of Arts and Sciences, 62, 93-120.

Wheeler, W.M. (1934) Revised list of Hawaiian ants. Occasional Papers of the Bernice P Bishop Museum, 10(21), 1-21.

Williams, D.F. (ed.) (1994) Exotic Ants. Biology, Impact, and Control of Introduced Species. Westview Press, Boulder, Colorado.

Wilson, E.O. (1992) The Diversity of Life. W.W. Norton Co., New York.

Wilson, E.O. (2005) Early ant plagues in the New World. Nature, 433, 32.

Wollaston, T.V. (1854) Insecta Maderensia; Being an Account of the Insects of the Islands of the Madeiran Group. Van Voorst, London.

Zimmerman, E.C. (1941) Argentine ant in Hawaii. Proceedings of the Hawaiian Entomological Society, 11, 108.

Zimmerman, E.C. (1948) Insects of Hawaii, Vol. 1. Introduction. University of Hawaii Press, Honolulu, Hawaii.

Accepted 12 December 2005 